2018-11-28

\title{
Intellectual capital profiles and financial performance of Islamic banks in the UK
}

Nawaz, T

http://hdl.handle.net/10026.1/13394

10.1504/IJLIC.2019.096934

International Journal of Learning and Intellectual Capital

Inderscience

All content in PEARL is protected by copyright law. Author manuscripts are made available in accordance with publisher policies. Please cite only the published version using the details provided on the item record or document. In the absence of an open licence (e.g. Creative Commons), permissions for further reuse of content should be sought from the publisher or author. 


\title{
Intellectual capital profiles and financial performance of Islamic banks in the UK
}

\section{Tasawar Nawaz}

Plymouth Business School

University of Plymouth

Plymouth

PL4 8AA

United Kingdom

\begin{abstract}
The main contribution of this paper is to report on the impact of intellectual capital (IC) on financial performance of Islamic banks operating in the United Kingdom (UK). Two distinct measures, return on average assets (ROAA) and return on average equity (ROAE) are used to measure the financial performance. The paper also controls for number of employees and bank size. Results based on the regression analysis suggest that IC efficiency proxied by the value added intellectual coefficient (VAIC) relates positively with financial performance of Islamic banks in the UK. The analysis further suggests that bank size and number of employees equally contribute in banks' achieving higher financial performance. Additionally, the paper further ghettoises sub-components of IC namely; capital employed, human capital and structural capital to analyse the discrete impact of these IC constituents on financial performance. The analysis of the sub components suggests a positive relationship between physical and financial capital employed efficiency, human capital efficiency and performance.
\end{abstract}

Keywords: Islamic banking and finance, intellectual capital efficiency, value added intellectual coefficient, financial performance, Islamic banks, United Kingdom. 


\section{Modern Islamic banking in the United Kingdom}

The roots of modern Islamic banking and finance in the United Kingdom (UK) can be traced back to the early 1980s when a Middle-eastern banking group, Al Barakah started its banking operations in the UK. However, the bank was forced to close in the early 1990s due to inflexibility by the UK financial regulatory authority. However, Islamic banking and finance strikes again in the beginning of the new millennium. This time it was a success. The UK Financial Services Authority, currently working as the Financial Conduct Authority (FCA) issued the first licence to Islamic Bank of Britain, currently operation under the name of $\mathrm{Al}$ Rayan Bank plc, in 2004 to operate as a fully-Shariah compliant retail Islamic bank in the UK. The bank is said to be the first Islamic bank to open its door in the West (see Nawaz, 2015).

Currently, there are seven Islamic financial institutions working in the UK. However, six banks namely; Al Rayan Bank, Bank of London and The Middle East, BLME Holdings, Gatehouse Bank, Qatar Islamic Bank (UK), and Rasmala plc, are actively engaged in retail and investment banking activities. There are several other conventional banks such Lloyds bank and HSBC bank offering interest free accounts and Islamic banking services, respectively. Additionally, there are several Shariah-compliant fund management and private equity investments companies operating within the sector. Moreover, several non-UK domiciled Islamic banks have opened their branches in the UK to cater the needs of their clients.

The rapid increase in number of financial institutions offering Shariah-compliant products and services in the UK hints the increased attention to Islamic way of banking in the UK and in the West in general. Islamic banking has reported sustained growth in the past two decades (Ernst \& Young, 2016; Nawaz, 2017a). It is therefore imperative to analyse the determinants of stable growth in Islamic banking and Islamic banks operating in the nonMuslim majority countries such as the UK. There is a lack of research on this topic. This study fills this research gap. 


\section{Value added intellectual coefficient}

The concept of value added here refers to the total value created by using the available physical, non-physical and financial resources. In other words, value creation in the context of current study refers to the profitability measured by average return on assets (ROAA) and average return on equity (ROAE). To simply it further, the paper attempts to test the relationship between tangle assets such as buildings machines, offices, desks, computers, copyrights and so forth as well intangible assets such as human capital i.e. knowledge skills and abilities of the employees in providing good customer services and financial performance. It is expected that the ability to achieve higher financial performance i.e. ROAA and ROAE be subject to the best utility of available resources including financial resources. All firms' resources are subsumed under intellectual capital, which is measured by the value added intellectual coefficient (VAIC). The proxy is consistent with the earlier research in the banking sectors around the word (see El-Bannany, 2008; Nawaz, 2018b), who reported a significant positive relationship between VAIC and bank performance. Accordingly, it is anticipated that;

Hypothesis 1: intellectual capital efficiency measured by VAIC relates positively with financial performance based on ROAA of Islamic banks operating in the UK

Hypothesis 2: intellectual capital efficiency measured by VAIC relates positively with financial performance based on ROAE of Islamic banks operating in the UK

\subsection{Capital employed efficiency}

Banks deal with money. They create money with money. Therefore, physical and financial capital, here referred to as the efficiency of capital employed is highly significant for banking business (Berger and Bouwman, 2013; Nawaz, 2013a). Islamic banks operate as interest free hence, profit is mainly generated through various investment projects rather than mainly 
relying on the interest income as it the case in conventional banking system. Therefore, it is important measure the impact of capital-employed efficiency on financial performance.

\author{
Hypothesis 3: capital employed efficiency relates positively with financial \\ performance based on ROAA of Islamic banks operating in the UK \\ Hypothesis 4: capital employed efficiency relates positively with financial \\ performance based on ROAE of Islamic banks operating in the UK
}

\title{
2.2 Human capital efficiency
}

Personal traits i.e. knowledge skills, abilities, capability to lead and innovate to satisfy the needs of customers and shareholders are all sorts of human capital. Usually, human capital resides within a person and that person willingly rents these talents to an organisation. The organisation then exploits these personal profiles to create value for the stakeholders (Nawaz, 2017d; Nawaz, 2017f; Nawaz, 2016b; Nawaz and Goj, 2013). Human capital is at the centre of intellectual capital (Stewart and Ruckdeschel, 1998). Like any other firm, human capital is important in the financial services sectors. Even more because it is human touch that encourages and convinces someone to put their money with a bank. Banks offer excellent customer services in person as well as through various sources to keep their clients banking with them. The client base of Islamic banks is somewhat different as they bank according to their religious believes. Therefore, human capital efficiency is delivery efficient services and satisfying the client needs is of paramount importance in Islamic banking and finance industry. Given the context of the present study, the human capital might be rare yet competent (Nawaz, 2017e; Nawaz, 2017f) given the significance of London as the financial hub for financial activities. Therefore, human capital efficiency is expected to have significant positive relationship with financial performance based on ROAA and ROAE. 
Hypothesis 5: human capital efficiency relates positively with financial performance based on ROAA of Islamic banks operating in the UK

Hypothesis 6: human capital efficiency relates positively with financial performance based on ROAE of Islamic banks operating in the UK

\subsection{Structural capital efficiency}

Structural capital is a combination of hard and soft firm resources such as tangible buildings, offices, desks, computers and software, databases and patents protected by the copyrights (Nawaz, 2018a; Nawaz, 2017a; Nawaz, 2017c; Nawaz and Goj, 2013). Organisations rent the human capital resources but they own the structural resources and they are reflected as asserts in their books (Nawaz, 2013b). These resources are essential to do business. On one hand, the help the employees to work better hence, enhancing their efficiency. On the other hand, they improve their own efficiency by being utilised in an efficient manner. These efficiencies are expected to relate with financial performance. Accordingly, the impact of structural capital efficiency is analysed;

Hypothesis 7: structural capital efficiency relates with financial performance based on ROAA of Islamic banks operating in the UK

Hypothesis 8: structural capital efficiency relates with financial performance based on ROAE of Islamic banks operating in the UK

\section{The UK financial services sector}

As stated above, the main objective of this research is to examine the impact of IC efficiency measured by value added intellectual coefficient (VAIC) and efficiency of sub-components of 
IC namely; capital employed efficiency, human capital efficiency and structural capital efficiency on financial performance based on return on average assets (ROAA) and return on average equity (ROAE) of Islamic banks operating in the UK financial services sector for the five years, 2013 to 2017 while controlling for bank size and number of employees.

Before focusing on the Islamic banks operating in the UK, it is essential to put the UK financial services sector at glance. The Orbis BankFocus Database suggests that over five hundred financial institutions are operating in the UK. These institutions are divided into fifteen different categories. These categories include

- Commercial Banks,

- Bank Holdings \& Holding Companies,

- Clearing \& Custody Institutions,

- Cooperative Banks,

- Finance Companies,

- Group Finance Companies,

- Investment Banks,

- Investment \& Trust Corporations,

- Islamic Banks,

- Other Non-banking Credit Institutions,

- Private Banking/Asset Management Companies,

- Real Estate \& Mortgage Banks,

- Saving Banks,

- Securities Firms, and

- Specialized Government Credit Institutions.

The above category clearly highlights the scope, depth, and diversity of financial services provided by the financial institutions in the UK. It is interesting to note that Islamic banks make 
only a fraction of the UK financial services sector however, the objective of this paper is not to measure the comparative impact of Islamic banks in the UK financial services sector. Instead, the research focuses on Islamic banks alone to measure the impact of IC on financial performance in the context of Islamic banks operating in the UK.

\subsection{Research sample}

The database showed seven Islamic banks operating in the UK. However, the data was available for six Islamic bank hence; they are include in the research accordingly. Table 1 illustrates the research sample used in the present study.

Table 1

Research sample profiles

\begin{tabular}{llllllll}
\hline Bank name & Listing & $\boldsymbol{E T}$ & $\boldsymbol{N E}$ & $\boldsymbol{W R A}$ & $\boldsymbol{C R A}$ & $\boldsymbol{W R E}$ & $\boldsymbol{C R} \boldsymbol{E}$ \\
\hline Al Rayan Bank & Unlisted & CS & 215 & 3572 & 109 & 4004 & 126 \\
BLME plc & Unlisted & CS & 123 & 4308 & 123 & 2832 & 100 \\
BLME Holdings & Listed & GUO & 117 & 4307 & 124 & 2831 & 101 \\
Gatehouse Bank & Unlisted & CS & 53 & 8243 & 184 & 3903 & 125 \\
Qatar Islamic Bank (UK) & Unlisted & CS & 36 & 6293 & 156 & 6546 & 176 \\
Rasmala & Listed & GUO & 74 & 12633 & 229 & 4680 & 138 \\
\hline
\end{tabular}

Notes: Listing =Listing position, ET =entity type, $\mathrm{CS}=$ controlled subsidiary, $\mathrm{GUO}=$ global ultimate owner, NE = No of employees, WRA =world-rank by assets, CRA =county-rank by assets, WRE =world-rank by equity, CRE =country-rank by equity, BLME =bank of London and the Middle East.

As grasped in Table 1, out of six two banks namely BLME Holdings and Rashala plc are listed while other four banks are unlisted. Similarly, the forgoing banks are global ultimate owner and the remaining four are controlled subsidiaries. In terms of total numbers of employees, Al Rayan Bank has the largest human capital base with 215 employees, followed by Bank of London and The Middle East and BLME Holdings with 123 and 117, respectively. The remaining three banks have less than one hundred employees. Rasmala plc, Gatehouse Bank and Qatar Islamic Bank (UK) have 74, 53 and 36 employees respectively. Turing to the rank by assets, it is noted that Rasmala plc is ranked lower in both world and country whereas $\mathrm{Al}$ 
Rayan Bank is ranked as the highest Islamic bank in the UK. In terms of rank on equity, Qatar Islamic Bank (UK) has lowest world rank by equity whereas Bank of London and The Middle East is ranked as highest Islamic bank by equity at country level.

\subsection{Dependent variables}

Two separate return of average assets (ROAA) and return on average equity (ROAE) are used to measure the dependent variable, the financial performance of Islamic banks operating in the UK. The use of these financial measures is consistent with the earlier research in the same filed (please see, Ahmad and Ahmed, 2016; Tahir et al., 2018; Nawaz, 2018a; Nawaz, 2017a). Data related to ROAA and ROAE and other financial data is derived from BankFocus database.

\subsection{Independent variables}

Intellectual capital efficiency is the main independent variable in this paper. Consistent with the previous research, IC efficiency is measured by using the value added intellectual coefficient (VAIC) methodology. The VAIC methodology was developed by Pulic (2000). The methodology is frequently used to measure the impact of IC in the financial and non-financial sector (among others, see, Hasan et al., 2017; Nawaz, 2017b; Nawaz, 2017c; Nawaz, 2016a).

VAIC is a combination of three variables namely capital employed efficiency, human capital efficiency and structural capital efficiency (Nawaz, 2018b). Value added is calculated by subtracting total expenses (excluding personal expenses) from total income. Capital employed is the sum of total physical and financial capital. Human capital is the sum of total personal expenses. Structural capital is difference between value added and human capital. The efficiency of each IC sub-component is calculated first. Capital employed efficiency is the ratio of physical and financial capital to value added. Human capital efficiency is the ratio of total 
personal expenses to value added. Structural capital is the ration of value added to structural capital. All three efficiencies are summed to calculate the VAIC.

\section{Research analysis}

The following section provides the statistics related to the dependent and independent variables used in this research study.

Table 2

Descriptive statistics and correlation matrix

\begin{tabular}{lllllll}
\hline Variables & $\boldsymbol{N}$ & Mean & Std. Dev. & Min. & Med. & Max. \\
\hline \multicolumn{7}{l}{ Panel B: descript statistics } \\
LnROAA & 30 & 0.755 & 0.905 & & & \\
LnROAE & 30 & 0.804 & 1.030 & -0.916 & 1.052 & 2.250 \\
VAIC & 30 & 0.645 & 0.200 & 0.334 & 0.740 & 0.875 \\
CEE & 30 & 4.002 & 1.086 & 5.792 & 3.845 & 2.402 \\
HCE & 30 & 0.138 & 1.115 & 4.705 & 0.083 & 1.418 \\
SCE & 30 & -1.031 & 1.287 & -2.940 & -0.745 & 0.881 \\
Bank & 30 & 0.075 & 0.006 & 0.067 & 0.077 & 0.083 \\
N $_{\text {Employees }}$ & 30 & 92.533 & 47.406 & 27 & 86.5 & 215 \\
\hline
\end{tabular}

Panel B: correlation matrix

\begin{tabular}{lllllllll}
\hline Variables & LnROAA & LnROAE & VAIC & CEE & HCE & SCE & Bank $_{\text {Size }}$ & $N_{\text {Employes }}$ \\
LnROAA & 1 & & & & & & & \\
LnROAE & $\mathbf{0 . 7 0 8}$ & 1 & & & & & & \\
VAIC & $\mathbf{0 . 6 6 3}$ & $\mathbf{0 . 9 0 1}$ & 1 & & & & & \\
CEE & 0.733 & 0.991 & 0.927 & 1 & & & & \\
HCE & $\mathbf{0 . 7 4 3}$ & 0.569 & $\mathbf{0 . 7 7 6}$ & $\mathbf{0 . 8 5 6}$ & 1 & & & \\
SCE & 0.797 & 0.939 & 0.872 & 0.961 & 0.978 & 1 & & \\
Bank & 0.466 & -0.078 & -0.204 & -0.222 & -0.286 & -0.126 & 1 & \\
N $_{\text {Employees }}$ & 0.254 & 0.127 & 0.155 & 0.164 & 0.1553 & 0.089 & $\mathbf{0 . 6 6 3}$ & 1 \\
\hline
\end{tabular}

Notes: LnROAA $=\log$ of return on average assets, LnROAE $=\log$ of return on average equity, VAIC =value added intellectual coefficient, CEE =capital employed efficiency, HCE =human

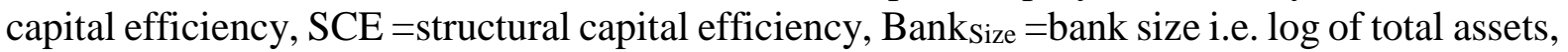
$\mathrm{N}_{\text {Employees }}=$ total number of employees.

The profiles are explained in Table 2 below, which provides the descriptive as well as the correlation analysis. Tale 2, panel A shows that the mean value of ROAA and ROAE is 0.76 and 0.80 , respectively. The positive value. Similarly, VAIC has a mean value of 0.65 . The sub- 
components of IC, capital employed efficiency and human capital efficiency have positive mean values of 4 and 0.14 , respectively whereas the mean value for structural capital efficiency is negative 1.03. The average employee size is 92.5. Panel B of Table 2 represents the correlation matrix for all the research variables. The $1 \%$ level of significant statistical results are highlighted in bold colour. No multicoliniarity can be found.

\subsection{Impact of intellectual capital (IC) on financial performance of Islamic banks}

Eight separate research models are used to analyse the impact of intellectual and it's subcomponents on financial performance of Islamic banks operating in the UK. These models are illustrated below.

$$
\begin{array}{lr}
\text { LnROAA }=\alpha+\beta 1 \text { VAIC }+\beta 2 \text { Bank }_{\text {Size }}+\beta 3 N_{\text {Employees }}+\varepsilon & \text { Eq. } 1 \\
\text { LnROAA }=\alpha+\beta 1 C E E+\beta 2 \text { Bank }_{\text {Size }}+\beta 3 N_{\text {Employees }}+\varepsilon & \text { Eq. } 2 \\
\text { LnROAA }=\alpha+\beta 1 H C E+\beta 2 \text { Bank }_{\text {Size }}+\beta 3 N_{\text {Employees }}+\varepsilon & \text { Eq. } 3 \\
\text { LnROAA }=\alpha+\beta 1 S C E+\beta 2 \text { Bank }_{\text {Size }}+\beta 3 N_{\text {Employees }}+\varepsilon & \text { Eq. } 4 \\
\text { LnROAE }=\alpha+\beta 1 \text { VAIC }+\beta 2 \text { Bank }_{\text {Size }}+\beta 3 N_{\text {Employees }}+\varepsilon & \text { Eq. } 5 \\
\text { LnROAE }=\alpha+\beta 1 C E E+\beta 2 \text { Bank }_{\text {Size }}+\beta 3 N_{\text {Employees }}+\varepsilon & \text { Eq. } 6 \\
\text { LnROAE }=\alpha+\beta 1 H C E+\beta 2 \text { Bank }_{\text {Size }}+\beta 3 N_{\text {Employees }}+\varepsilon & \text { Eq. } 7 \\
\text { LnROAE }=\alpha+\beta 1 S C E+\beta 2 \text { Bank }_{\text {Size }}+\beta 3 N_{\text {Employees }}+\varepsilon & \text { Eq. } 8
\end{array}
$$

Where;

LnROAA $=\log$ of return on average assets,

$\mathrm{LnROAE}=\mathrm{Log}$ of return on average equity,

VAIC $=$ Value added intellectual coefficient

$\mathrm{CEE}=$ Capital employed efficiency

$\mathrm{HCE}=$ Human capital efficiency

$\mathrm{SCE}=$ Structural capital efficiency

Bank $_{\text {Size }}=$ Bank size i.e. $\log$ of total assets

$\mathrm{N}_{\text {Employees }}=$ Total number of employees

$\alpha=$ constant

$\varepsilon=$ the error term. 
Equation 1 to 4 are used measure the impact of IC and its sub-components on return on average assets (ROAA). Equation 5 to 8 are used to measure the impact of IC and its sub-components on return on average equity (ROAE). Results for each financial measure, ROAA and ROAE are provided in Table 3 and Table 4 below.

\subsubsection{Impact of intellectual capital (IC) on ROAA}

Four research models are used to analyse the impact of IC on return on average assets (ROAA). Results are provided in Table 3 below.

Table 3

Econometric analysis for return on average assets (ROAA)

\begin{tabular}{|c|c|c|c|c|c|}
\hline & & Eq. 1 & Eq. 2 & Eq. 3 & Eq. 4 \\
\hline Variables & $\begin{array}{l}\text { Predicted } \\
\text { Sign }\end{array}$ & ROAA & ROAA & ROAA & ROAA \\
\hline \multicolumn{6}{|c|}{ Composite intellectual capital efficiency } \\
\hline VAIC & + & $3.387 * * *$ & & & \\
\hline Banksize & + & $102.2 * * *$ & $58.84^{*}$ & $62.67 * *$ & $86.38^{*}$ \\
\hline $\mathrm{N}_{\text {Employees }}$ & $+/-$ & $0.00432 * *$ & -0.00514 & -0.00218 & 0.000904 \\
\hline \multicolumn{6}{|c|}{ Constituents of intellectual capital efficiency } \\
\hline CEE & + & & $26.35 * * *$ & & \\
\hline HCE & + & & & $1.847 * * *$ & \\
\hline SCE & + & & & & -0.0150 \\
\hline Constant & & $11.09 * * *$ & $5.425 * *$ & $6.067 * *$ & $-7.052 *$ \\
\hline Observations & & 30 & 30 & 30 & 30 \\
\hline Adj. $R^{2}$ & & 0.686 & 0.585 & 0.724 & 0.194 \\
\hline
\end{tabular}

Notes: $* * * \mathrm{p}<0.01, * * \mathrm{p}<0.05, * \mathrm{p}<0.1$.

The impact of IC and its constituents on return on average assets (ROAA) is provided is Table 3. As can be seen IC efficiency measured by the value added intellectual coefficient (VAIC) relates positively with ROAA, results are provided in column three of Table 3 . The results support hypothesis $\left(\mathrm{H}_{1}\right)$. These results are consistent with the earlier findings of Hasan et al. 
(2017) and Nawaz (2016), who measured the impact of IC on performance of Islamic and conventional banks in Bangladesh and serval other countries around worldwide, respectively. The results are consistent with Tahir et al. (2018), who analysed the financial services firms in Pakistan. Similarly, bank size and number of employees relate positively with ROAA at $1 \%$ and 5\% level of significance, respectively. This suggest that Islamic banks larger in size with larger work force be likely to offer higher ROAA.

The impact of constituents of intellectual capital (IC) on ROAA is analysed separately using equation 2, 3 and 4. Equation 2 measures the impact of capital-employed efficiency (CEE) on ROAA. Results are supplied in column four of Table 3, which suggests a significant positive relationship at $1 \%$ level of statistical significance. This supports hypothesis $\left(\mathrm{H}_{3}\right)$. These results are consistent with Nawaz (2016) who analysed the Islamic banking and finance industry.

Similarly, equation 3 measures the impact of human capital efficiency (HCE) on ROAA. Results are supplied in column five of Table 3, which suggests a significant positive relationship at $1 \%$ level of statistical significance between HCE and ROAA. This supports hypothesis $\left(\mathrm{H}_{5}\right)$. These results are consistent with Ahmad and Ahmed (2016), who reported a significant positive relationship between human capital efficiency and financial performance of Islamic banks in Pakistan.

Finally, equation 4 measures the impact of structural capital efficiency (SCE) on ROAA. Results are supplied in column six of Table 3, which suggests no statistically significant relationship between SCE and ROAA. This does not support hypothesis $\left(\mathrm{H}_{7}\right)$.

\subsubsection{Impact of intellectual capital (IC) on ROAE}

As above, four research models are used to analyse the impact of IC on return on average equity (ROAE). Results are provided in Table 4 below. 


\section{Table 4}

Econometric analysis for return on average equity (ROAE)

\begin{tabular}{|c|c|c|c|c|c|}
\hline & & Eq. 5 & Eq. 6 & Eq. 7 & Eq. 8 \\
\hline Variables & $\begin{array}{l}\text { Predicted } \\
\text { Sign }\end{array}$ & ROAE & ROAE & $R O A E$ & $\boldsymbol{R O A E}$ \\
\hline \multicolumn{6}{|c|}{ Composite intellectual capital efficiency } \\
\hline VAIC & + & $4.641 * * *$ & & & \\
\hline Bank $_{\text {Size }}$ & + & 32.70 & 9.994 & 14.17 & 17.30 \\
\hline $\mathrm{N}_{\text {Employees }}$ & $+/-$ & $0.00507^{*}$ & 0.00158 & 0.00341 & 0.00302 \\
\hline \multicolumn{6}{|c|}{ Constituents of intellectual capital efficiency } \\
\hline CEE & + & & 14.65 & & \\
\hline HCE & + & & & 0.900 & \\
\hline SCE & + & & & & -0.0145 \\
\hline Constant & & $5.229 * *$ & 0.172 & 0.636 & -0.456 \\
\hline Observations & & 30 & 30 & 30 & 30 \\
\hline Adj. $R^{2}$ & & 0.824 & 0.427 & 0.387 & 0.208 \\
\hline
\end{tabular}

Notes: $* * * \mathrm{p}<0.01, * * \mathrm{p}<0.05, * \mathrm{p}<0.1$.

The impact of IC and its constituents on return on average equity (ROAE) is provided is Table 4. As can be seen IC efficiency measured by the value added intellectual coefficient (VAIC) relates positively with ROAE, results are provided in column three of Table 4 . The results support hypothesis $\left(\mathrm{H}_{2}\right)$ that IC efficiency relates positively with financial performance in Islamic banking, measured by ROAE. These results are consistent with the earlier findings of El-Bannany (2008), who reported a significant positive relationship between IC efficiency and performance of banks operation in the UK. Unlike ROAA, only number of employees relate positively with ROAA at $10 \%$ level of significance, suggesting that Islamic banks with larger work force are likely to offer higher return on average equity (ROAA) in the UK.

As before, the impact of constituents of intellectual capital (IC) on ROAE is analysed separately using equation 6,7 and 8 . Equation 6 measures the impact of capital-employed efficiency (CEE) on ROAE. Results are supplied in column four of Table 4, which suggests no 
statistically significant relationship between CEE and ROAE. Likewise, equation 7 measures the impact of human capital efficiency (HCE) on ROAE. Results are supplied in column five of Table 4, which suggests no statistically significant relationship between HCE and ROAE. Lastly, equation 8 measures the impact of structural capital efficiency (SCE) on ROAE. Results are supplied in column six of Table 4, which suggests no statistically significant relationship between SCE and ROAE. Hence, hypotheses $\left(\mathrm{H}_{4}\right),\left(\mathrm{H}_{6}\right)$, and $\left(\mathrm{H}_{8}\right)$ are not supported.

\section{Summary and conclusion}

The main objective of this paper was to empirically investigate the impact of intellectual capital (IC) efficiency on financial performance of Islamic banks operating in the UK. Two distinct measures, return on average assets (ROAA) and return on average equity (ROAE) were used to measure financial performance from 2013 to 2017 . The paper also controlled for bank size and number of employees. Results based on the regression analysis suggest that IC efficiency proxied by the value added intellectual coefficient (VAIC) relates positively with financial performance of the selected Islamic banks in the UK. The analysis further suggests that bank size and number of employees equally contribute in banks' achieving higher financial performance. Additionally, the paper further ghettoises sub-components of IC namely; capital employed, human capital and structural capital to analyse the discrete impact of these resources on financial performance. The analysis of the sub components suggests a positive relationship between capital employed efficiency, human capital efficiency and performance.

The separate analysis further suggest that capital employed efficiency and human capital efficiency drive ROAA. The ROAA is equally driven by the bank size in all models. Similarly, number of employees drive ROAA in the main model only, which measures the impact of VAIC on financial performance. The results for ROAE are statistically less strong. 
VAIC relates with ROAE however, the separate analysis does not show any statistical significance been the sub-components of IC and ROAE. Similarly, the contribution of bank size and number of employees is also shallow.

This is the first study to measure the IC efficiency of Islamic banks in the UK. The study hopes to encourage future researchers to expand the insights observed in this study further by performing a comparative analysis between Islamic band conventional banks operating the West, UK or elsewhere. 


\section{References}

Ahmad, M. and Ahmed, N., 2016. Testing the relationship between intellectual capital and a firm's performance: an empirical investigation regarding financial industries of Pakistan. Int. J. of Learning and Intellectual Capital, 13(2-3), pp.250-272.

Berger, A.N. and Bouwman, C.H., 2013. How does capital affect bank performance during financial crises? Journal of Financial Economics, 109(1), pp.146-176.

Ernst \& Young 2016. World Islamic banking competitiveness report 2016. New realities new opportunities Google Scholar. Available at (accessed at 6 June 2018): http://www.ey.com/Publication/vwLUAssets/ey-world-islamic-bankingcompetitiveness-report-2016/\%24FILE/ey-world-islamic-banking-competitivenessreport-2016.pdf.

El-Bannany, M., 2008. A study of determinants of intellectual capital performance in banks: the UK case. Journal of Intellectual Capital, 9(3), pp.487-498.

Hasan, R., Mohammad, N. and Alam, M.F., 2017. Impact of Intellectual Capital on Profitability-Conventional versus Islamic Banks. Journal of Accounting, Finance and Auditing Studies, 3(2), pp.64-80.

Nawaz, T., 2018a. Determinants and consequences of disruptive innovations: evidence from the UK financial services sector. Accounting and Management Information Systems. 17(2), pp.234-251.

Nawaz, T., 2018b. Lifting the Lid on Financial Inclusion: Evidence from Emerging Economies. International Journal of Financial Studies, 6(2), pp.1-8.

Nawaz, T., 2017a. Exploring the Nexus between Human Capital, Corporate Governance and Performance: Evidence from Islamic Banks. Journal of Business Ethics, DOI: 10.1007/s10551-017-3694-0.

Nawaz, T., 2017b. Momentum investment strategies, corporate governance and firm performance: an analysis of Islamic banks. Corporate Governance: The International Journal of Business in Society, 17(2), pp.192-211.

Nawaz, T., 2017c. Intellectual capital, financial crisis and performance of Islamic banks: Does Shariah governance matter? International Journal of Business and Society, 18(1), pp.211-226. 
Nawaz, T., 2017d. Islamic Banking: An Ultimate Source of Financial Inclusion. International Journal of Social, Behavioral, Educational, Economic, Business and Industrial Engineering, 11(8), pp. 2047-2050.

Nawaz, T., 2017e. Human capital development in socio-economic malaise: evidence from the UK. International Journal of Learning and Intellectual Capital, 14(1), pp.24-46.

Nawaz, T., 2017f. Conventional vs. Islamic banks in dual-banking systems: business model, outlay stratagems and economic performance. International Journal of Business Governance and Ethics, 12(4), pp.330-348.

Nawaz, T., 2016a. Determinants of sustainable growth: a comparative analysis of conventional and Islamic banks. Corporate Ownership \& Control, 4(1) pp.403-413.

Nawaz, T., 2016b. Expatriation in the age of austerity: an analysis of capital mobilization strategies of self-initiated expatriates in the Handbook of Research on Human Resources Strategies for the New Millennial Workforce, pp.177-199, IGI Global, USA.

Nawaz, T., 2015. Ethical Banking in the Land of Redistributive Policies, Scholars Press, Saarbruchen, Germany.

Nawaz, T., 2013a. How serious is the Erudite Shariah-compliant Business in Europe? Evolution, Pivotal Challenges and the way forward. European Journal of Management and Management, 4(6), pp.226-235.

Nawaz, T., 2013b. Blind-trust - a Pave Stone for Islamic Financial Institutions. Research Journal of Finance and Accounting, 4(6), pp.226-235.

Nawaz, T. and Goj, T., 2013. Intellectual Capital: A Synthesis of Current Research with Special Reference to Islamic Banking and Finance. International Journal of Business and Management Studies, 2(1): pp.303-317.

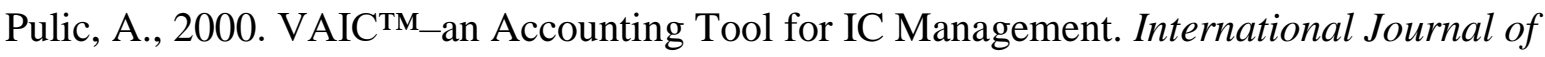
Technology Management, 20(5); pp.702-714.

Stewart, T. and Ruckdeschel, C., 1998. Intellectual capital: The new wealth of organizations. New York: Doubleday/Currency.

Tahir, M., Shah, A., Khan, M.M. and Afridi, M.A., 2018. Intellectual Capital and Financial Performance of Banks in Pakistan. Dialogue, 13(1): pp. 1819-6462. 